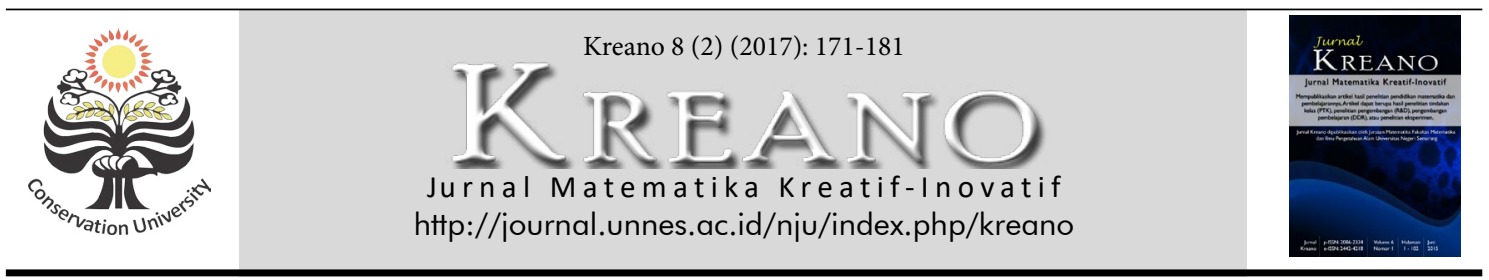

\title{
Profil Berpikir Reflektif Siswa SMP dalam Pemecahan Masalah Pecahan Ditinjau dari Perbedaan Gender
}

\author{
Muh. Anis Rasyid', Mega Teguh Budiarto², Agung Lukito ${ }^{3}$ \\ 1,2,3Pendidikan Matematika, Universitas Negeri Surabaya \\ Email: muh.rasyid@mhs.unesa.ac.id',mega.t.budiarto@unesa.ac.id², \\ agunglukito@unesa.ac.id ${ }^{3}$
}

DOI: http://dx.doi.org/10.15294/kreano.v8i2.9849

Received : May 2017; Accepted: June 2017; Published: December 2017

\begin{abstract}
Abstrak
Penelitian ini bertujuan untuk mendeskripsikan berpikir reflektif siswa SMP dalam pemecahan masalah pecahan ditinjau dari perbedaan gender. Penelitian ini merupakan penelitian deskriptif dengan pendekatan kualitatif. Subjek pada penelitian ini yaitu, satu siswa laki-laki dan satu siswa perempuan di kelas VIIB SMPN 2 Kodeoha. Pengambilan data dimulai dengan memberikan tes kemampuan matematika untuk mendapatkan subjek yang berkemampuan tinggi, kemudian memperhatikan perbedaan gender. Setelah itu, memberikan tugas pemecahan masalah pecahan dan melakukan wawancara. Hasil penelitian menunjukkan, subjek laki-laki melakukan reacting, elaborating dan contemplating pada tahap memahami masalah, menyusun rencana, melaksanakan rencana dan memeriksa kembali dalam pemecahan masalah pecahan. Sedangkan, subjek perempuan melakukan reacting, elaborating dan contemplating pada tahap memahami masalah, menyusun rencana, melaksanakan rencana dan memeriksa kembali dalam pemecahan masalah pecahan. Namun, pada tahap menyusun rencana, subjek perempuan melakukan contemplating hanya sebatas meyakini tanpa mempertimbangkan berdasarkan pengalamannya dalam pemecahan masalah pecahan.
\end{abstract}

\begin{abstract}
The study aimed at describing the junior high school students' reflective thinking in fraction problem solving viewed on gender differences. This study employed descriptive research with qualitative approach. The research subjects were one male student and one female student in VIIB class of SMPN 2 Kodeoha. The data collection was started by giving mathematics ability test to get a subject highly capable, then paid attention of the gender differences. After that, give fraction problem solving task and did the interview. The results of the study showed that male subjects did reacting, elaborating and contemplating on understanding the problems, devising a plan, carrying out the plan and looking back stages in a fraction problem solving. Whereas, female subjects did reacting, elaborating and contemplating on understanding the problems, devising a plan, carrying out the plan and looking back stages in a fraction problem solving. But, at the stage of devise a plan, female subjects did contemplating only a believing without consideration based on his experience in problem solving fractions.
\end{abstract}

Keywords: reflective thinking; problem solving; fraction; gender differences

\section{PENDAHULUAN}

Matematika berperan sebagai sarana mengembangkan daya nalar, karena belajar matematika berarti belajar cara mengembangkan kemampuan berpikir. Oleh sebab itu, matematika dapat dipandang sebagai cara berpikir, sebagaimana dikemukakan Jacob \&
Sam (2008) bahwa, matematika tidak hanya dipandang sebagai cabang ilmu pengetahuan dan mata pelajaran, tetapi juga dipandang sebagai cara siswa berpikir. Berpikir merupakan suatu kegiatan mental yang melibatkan kerja otak, dan seseorang dikatakan berpikir bila orang itu melakukan kegiatan mental (Hudo- 
jo, 2003). Jadi, berpikir merupakan satu kegiatan mental pribadi manusia yang mengakibatkan penemuan yang terarah kepada suatu tujuan. Pada aspek yang lain, berpikir merupakan kemampuan untuk menyelesaikan masalah atau tugas dan menyelesaikannya dengan cara cerdas dan rasional sehingga dapat memberikan penjelasan yang masuk akal atau logis (Tomasello, 2014; Ngang, Nair, \& Pracak, 2013). Salah satu harapan dan tujuan penting yang harus dicapai oleh siswa dalam belajar matematika, yakni memiliki kemampuan berpikir, sebagaimana yang tercantum dalam Peraturan Menteri Pendidikan Nasional Republik Indonesia nomor 23 tahun 2006 tentang Standar Kompetensi Lulusan (SKL) untuk Satuan Pendidikan Dasar dan Menengah.

Berkaitan dengan kemampuan berpikir, Meissner (2006) menyatakan bahwa perkembangan berpikir reflektif merupakan pusat pendidikan matematika. Ini menunjukkan bahwa perkembangan berpikir reflektif telah menjadi sorotan dan merupakan hal yang penting dalam pendidikan matematika, ditambah lagi, berpikir reflektif dapat diterapkan dalam pembelajaran matematika (Odafe, 2008) dan berpikir reflektif adalah unsur yang paling penting untuk belajar secara efektif (Van De Walle, 2008). Pendapat para ahli ini dapat mendasari pentingnya mengetahui berpikir reflektif. Berpikir reflektif merupakan salah satu kemampuan berpikir tingkat tinggi, sebagaimana dikemukakan oleh King, Gudson, \& Rohani (2013).

Definisi berpikir reflektif yang dikemukakan oleh Dewey (1933) menjelaskan bahwa berpikir reflektif adalah pertimbangan yang aktif, terus menerus dan teliti mengenai sebuah keyakinan atau bentuk pengetahuan yang diterima begitu saja dipandang dari sudut alasan-alasan yang mendukungnya hingga menuju pada kesimpulan yang menjadi kecenderungan akan kebenaran keyakinan tersebut (Fisher, 2008). Sezer (Choy \& Oo, 2012) menyatakan, berpikir reflektif merupakan kesadaran tentang apa yang diketahui dan apa yang dibutuhkan, hal ini sangat penting untuk menjembatani kesenjangan situasi dalam belajar. Surbeck, Han, \& Moyer (1991) menyatakan bahwa ada tiga komponen dalam berpikir reflektif, yaitu reacting, elaborating dan con- templating. Jadi, berpikir reflektif adalah aktivitas mental seseorang untuk mengidentifikasi masalah dan memecahkan masalah dengan menggunakan pengetahuan dan pengalaman yang berkaitan dengan masalah yang dihadapi, dan melakukan komponen-komponen berpikir reflektif, yaitu reacting, elaborating dan contemplating.

Kemampuan berpikir reflektif perlu dimiliki seseorang, karena dia dapat memahami, mengkritik, menilai, mencari solusi alternatif dan mengevaluasi isu-isu atau masalah yang sedang dipelajari dengan memiliki kemampuan berpikir reflektif (Muin, 2011) dan kemampuan berpikir reflektif berkesempatan dimunculkan dan dikembangkan ketika siswa sedang berada dalam proses yang intens tentang pemecahan masalah (Sabandar, 2010). Sejalan dengan pendapat Rudd (Choy \& Oo, 2012) bahwa, peran penting dari berpikir reflektif adalah bertindak sebagai sarana untuk mendorong pemikiran selama situasi pemecahan masalah, karena memberikan kesempatan untuk menggunakan pengetahuan dan pengalaman yang berkaitan dengan masalah yang dihadapi dan memikirkan strategi terbaik untuk mencapai tujuan. Hal ini menunjukkan, pentingnya berpikir reflektif dalam pembelajaran matematika, terutama dalam memecahkan masalah matematika.

Fokus dalam pembelajaran matematika, yakni pemecahan masalah, karena pemecahan masalah menduduki posisi yang penting dalam pembelajaran matematika dan merupakan inti dari kurikulum matematika. National Council of Teacher of Mathematics (NCTM, 2000) memublikasikan pemecahan masalah sebagai salah satu standar penting dalam pembelajaran matematika. Siswa memungkinkan memperoleh pengalaman menggunakan pengetahuan serta keterampilan yang sudah dimiliki untuk diterapkan pada pemecahan masalah yang bersifat tidak rutin (Suherman, 2001). Polya (1973) menjelaskan strategi dalam memecahkan masalah ada empat langkah, yaitu memahami masalah (understanding the problem), membuat rencana (make a plan), melaksanakan rencana (carrying out the plan) dan memeriksa kembali hasil yang diperoleh (looking back).

Pada penelitian ini, peneliti memilih 
materi pecahan karena masih banyaknya siswa yang belum menguasai pecahan khususnya dalam bentuk soal cerita dan hal itu berdampak terhadap penguasaan materi siswa pada materi aljabar tingkat lanjut. Sejalan hal itu, Fisher (2009) menyatakan, materi pecahan itu sulit. Hal ini disebabkan karena pecahan termasuk materi yang cukup kompleks dan sulit dipelajari oleh siswa (Lamon, 2012) dan tak satu pun bidang dalam matematika sekolah sekaya, sekompleks dan sesulit untuk mengajarkannya seperti pecahan (Clarke, Roche \& Mitchell, 2008). Selanjutnya, memilih siswa SMP sebagai subjek penelitian dikarenakan siswa SMP berada pada usia 11 - 15 tahun. Menurut Piaget, pada usia itu, kemampuan berpikir siswa sudah termasuk pada tahap operasional formal. Tahap ini, siswa sudah mampu berpikir abstrak dan logis, memiliki pengetahuan dasar dan pengalaman yang sesuai dengan masalah yang diberikan, sehingga memungkinkan berpikir lebih fleksibel dalam memikirkan kemungkinan yang lebih banyak dalam pemecahan masalah.

Perbedaan gender sudah menjadi sorotan sejak dahulu dan merupakan istilah yang digunakan secara luas dalam kehidupan kita sehari-hari, termasuk sekolah dan pendidikan (Santrock, 2011). Perbedaan ini memungkinkan adanya pengaruh dalam belajar dan berkembang pada perbedaan kemampuan laki-laki dan perempuan. Zhu (2007) dalam penelitiannya menyimpulkan laki-laki dan perempuan memiliki preferensi yang berbeda dalam penggunaan strategi pemecahan masalah. Selain itu, penelitian Pargulski \& Reynolds (2017), menunjukkan laki-laki memiliki keunggulan yang kecil dibandingkan dengan perempuan dalam pemecahan masalah matematika. Kaitannya dengan berpikir reflektif, Demirel, Derman, \& Karagedik (2015) dalam penelitiannya menunjukkan bahwa pada proses pemecahan masalah matematika dengan menggunakan kemampuan berpikir reflektif bergantung pada perbedaan gender. Sedangkan penelitian yang dilakukan Tuncer \& Ozeren (2012) menunjukkan bahwa tidak ada perbedaan yang signifikan antara berpikir reflektif mahasiswa laki-laki dan berpikir reflektif mahasiswa perempuan dalam pemecahan masalah. Oleh sebab itu, dalam berpikir reflektif pada pemecahan masalah perlu memperhatikan perbedaan gender siswa. Mengingat adanya keterkaitan tersebut, peneliti tertarik untuk mendeskripsikan berpikir reflektif siswa SMP dalam pemecahan masalah pecahan ditinjau dari perbedaan gender. Adapun tujuan penelitian ini, yaitu untuk mendeskripsikan berpikir reflektif siswa SMP laki-laki dan perempuan dalam pemecahan masalah pecahan.

\section{METODE}

Penelitian ini merupakan penelitian deskriptif dengan pendekatan kualitatif. Subjek pada penelitian ini, yaitu satu laki-laki dan satu perempuan pada kelas VIIB SMPN 2 Kodeoha, Kecamatan Tiwu, Kabupaten Kolaka Utara, Sulawesi Tenggara. Pemilihan subjek dengan memberikan tes kemampuan matematika untuk memilih siswa kemampuan matematika tinggi, kemudian memperhatikan perbedaan gender. Setelah itu, kedua subjek diberikan tugas pemecahan masalah pecahan, kemudian melakukan wawancara. Pemberian tugas pemecahan masalah pecahan dan wawancara dilakukan sebanyak dua kali. Setelah memperoleh data, selanjutnya dilakukan triangulasi waktu dan kedua data tersebut menunjukkan kekonsistenan, sehingga data tersebut valid. Analisis data pada penelitian ini, yaitu kondensasi data, penyajian data, dan penarikan kesimpulan dan memverifikasi (Miles, Huberman \& Saldaña, 2014).

\section{HASIL DAN PEMBAHASAN}

\section{Profil Berpikir Reflektif Subjek Laki- laki dalam Pemecahan Masalah Pecahan}

Berdasarkan hasil penelitian, subjek laki-laki melakukan semua komponen berpikir reflektif melalui tahapan-tahapan pemecahan masalah. Profil berpikir reflektif subjek laki-laki pada komponen reacting dalam pemecahan masalah pecahan, dapat dilihat pada diagram berikut. 


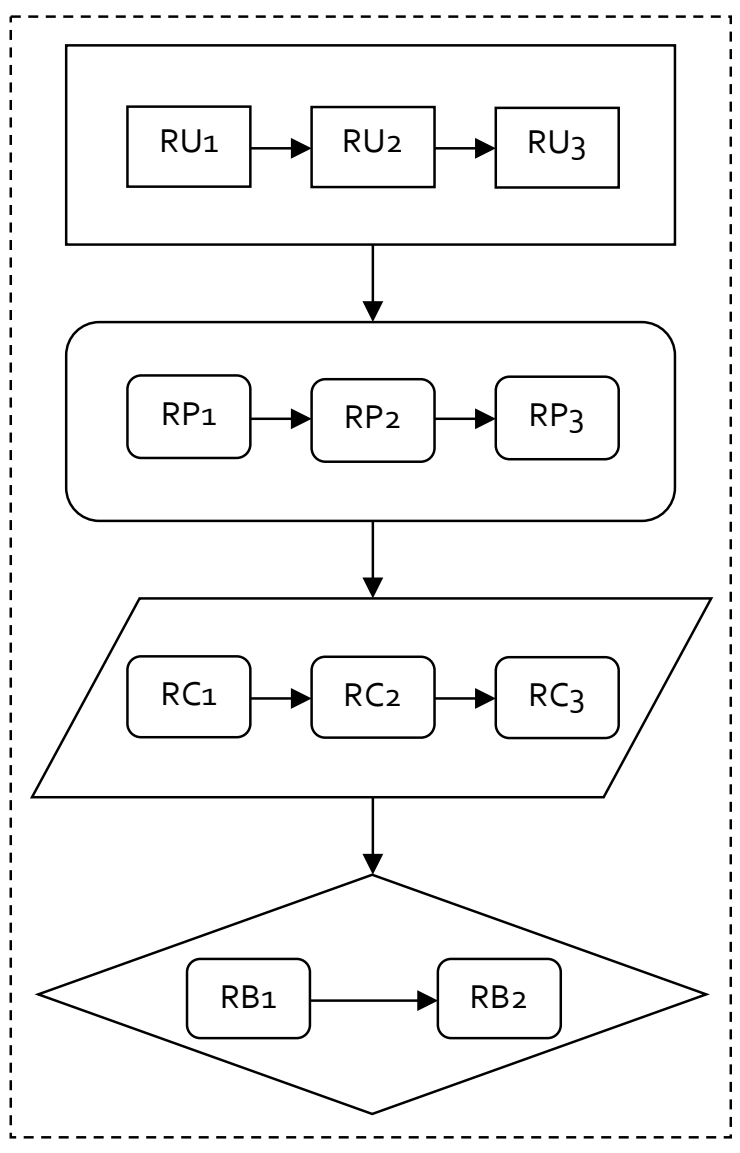

Gambar 1 Berpikir Reflektif Subjek Laki-laki pada

Komponen Reacting dalam Pemecahan Masalah

\section{Pecahan Keterangan:}

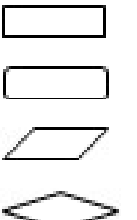

Memahami masalah.

Menyusun rencana.

Melaksanakan rencana.

Memeriksa kembali.

Mengomentari perasaan terhadap

$\mathrm{RU}_{1}$ : pengalamannya dari masalah yang diberikan.

Mengomentari dengan mengidentifikasi

$\mathrm{RU}_{2}$. dan mengungkapkan kembali apa yang diketahui dan apa yang ditanyakan pada masalah yang diberikan.

Mengomentari berdasarkan pengala-

$\mathrm{RU}_{3}$ : mannya terkait informasi pada masalah yang diberikan.

Mengomentari perasaan terhadap pen-

$\mathrm{RP}_{1}$ : galamannya dalam menyusun rencana pada masalah yang diberikan.

Mengomentari terhadap pengalamannya dengan menyebutkan rencana yang akan dilakukan untuk memecahkan masalah yang diberikan.

\section{Mengemukakan alasannya memilih strategi/ metode/langkah-langkah tersebut.}

Mengomentari perasaan mengenai

$\mathrm{RC}_{1}$. langkah-langkah/perhitungan yang telah dilakukan dalam memecahkan masalah yang diberikan.

Mengomentari terhadap pengalaman-

$\mathrm{RC}_{2}$ : nya terkait strategi/metode/langkahlangkah untuk memecahkan masalah yang diberikan.

Mengomentari langkah yang telah di-

$\mathrm{RC}_{3}$. lakukan dan kesesuaian rencana dengan langkah yang telah dilakukan untuk memecahkan masalah yang diberikan.

Mengomentari perasaan mengenai

RB1 langkah-langkah yang telah dilakukan memperoleh solusi dari masalah yang diberikan.

Mengomentari terhadap pengalaman-

$\mathrm{RB}_{2}$ : nya terkait mengenai perlunya memeriksa kembali pekerjaannya dan melihat kembali hasil akhir yang diperoleh.

: Alur berpikir reflektif.

Pada komponen reacting, subjek lakilaki mengomentari perasaannya terhadap pengalaman-pengalaman yang dimiliki terkait masalah pecahan yang diberikan, sehingga dia mengidentifikasi dan mengungkapkan kembali informasi-informasi dari masalah pecahan berdasarkan pengalamannya, menyusun rencana berdasarkan pengalamannya, melaksanakan rencana berdasarkan pengalamannya melakukan dan memeriksa kembali. Hal ini sesuai dengan yang dikemukakan Sezer (Choy \& Oo, 2012) bahwa, siswa yang berpikir reflektif menjadi sadar tentang apa yang mereka ketahui dan apa yang mereka butuhkan. Selanjutnya, subjek laki-laki selalu menggunakan pengalaman-pengalaman yang dimilikinya dalam memecahkan masalah pecahan. Sebagaimana yang dikemukakan Rodgers (2002) bahwa, berpikir reflektif adalah proses bermakna yang memindahkan siswa dari suatu pengalaman ke pengalaman selanjutnya dengan pemahaman yang lebih mendalam tentang hubungannya dengan pengalaman dan ide yang lain.

Profil berpikir reflektif subjek laki-laki pada komponen elaborating dalam pemecahan masalah pecahan, dapat dilihat pada diagram berikut. 


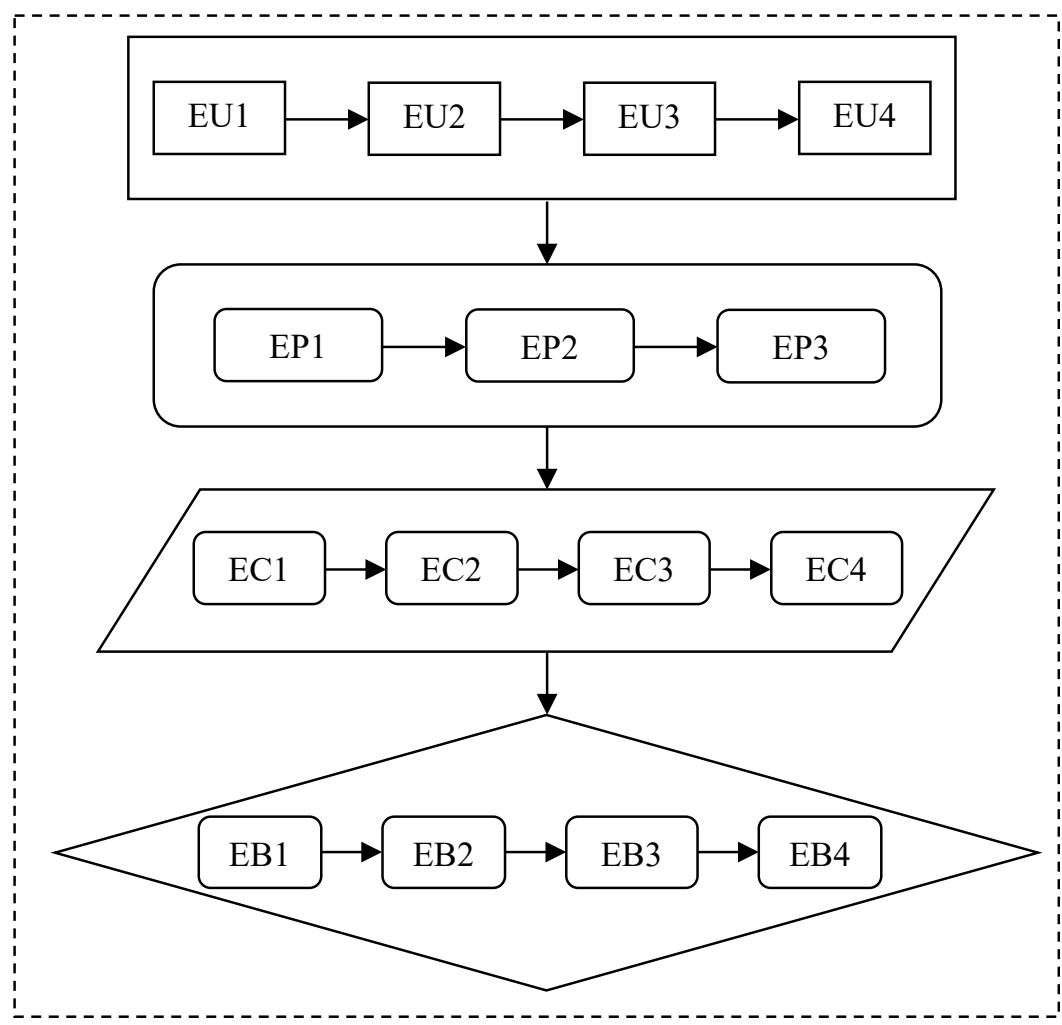

Gambar 2 Berpikir Reflektif Subjek Laki-laki pada Komponen Elaborating dalam Pemecahan Masalah Pecahan

Keterangan:

\begin{tabular}{|c|c|c|}
\hline & . & Memahami masalah. \\
\hline & : & Menyusun rencana. \\
\hline & : & Melaksanakan rencana. \\
\hline & : & Memeriksa kembali. \\
\hline $\mathrm{EU}_{1}$ & : & $\begin{array}{l}\text { Menyebutkan pengalamannya yang } \\
\text { berhubungan dengan masalah yang } \\
\text { diberikan. }\end{array}$ \\
\hline $\mathrm{EU}_{2}$ & : & $\begin{array}{l}\text { Menyebutkan persamaan dan per- } \\
\text { bedaan dengan pengalamannya } \\
\text { berkaitan informasi yang diberikan } \\
\text { pada masalah. }\end{array}$ \\
\hline $\mathrm{EU}_{3}$ & : & Menyebutkan sebuah konsep/definisi. \\
\hline $\mathrm{EU}_{4}$ & : & $\begin{array}{l}\text { Menjelaskan kaitan antara informasi } \\
\text { yang diperoleh. }\end{array}$ \\
\hline EP1 & : & $\begin{array}{l}\text { Menyebutkan dan menjelaskan pen- } \\
\text { galamannya dalam menyusun rencana. }\end{array}$ \\
\hline$E P_{2}$ & : & $\begin{array}{l}\text { Menyebutkan persamaan dan per- } \\
\text { bedaan dengan pengalamannya } \\
\text { terkait strategi/metode/langkah-lang- } \\
\text { kah yang direncanakan. }\end{array}$ \\
\hline $\mathrm{EP}_{3}$ & : & $\begin{array}{l}\text { Menyebutkan rencana lain atau cara } \\
\text { lain untuk memecahkan masalah yang } \\
\text { diberikan. }\end{array}$ \\
\hline $\mathrm{EC} 1$ & : & $\begin{array}{l}\text { Menyebutkan dan menjelaskan pen- } \\
\text { galamannya melakukan dalam melak- } \\
\text { sanakan rencana. }\end{array}$ \\
\hline
\end{tabular}

EC2 : Menyebutkan persamaan dan perbedaan dengan pengalamannya terkait strategi/metode/langkah-langkah yang telah dilakukan.

$\mathrm{EC}_{3}$ : Menjelaskan hubungan setiap langkah yang telah dilakukan dalam memecahkan masalah yang diberikan.

EC4 : Menyebutkan dan menjelaskan cara atau langkah lain untuk memecahkan masalah yang diberikan.

EB1 : Menyatakan terhadap pengalamannya bahwa selalu memeriksa kembali jawabannya.

EB2 : Menyebutkan persamaan dan perbedaan dengan pengalamannya terkait memeriksa kembali solusi yang diperoleh.

EB3 : Mengungkapkan kesesuaian yang diperoleh dengan strategi/metode/ langkah-langkah yang telah direncanakan dan atau yang telah dilakukan.

EB4 : Menuliskan alternatif penyelesaian yang lain dan alternatif pemecahan yang terbaik.

Alur berpikir reflektif.

Pada komponen elaborating, subjek laki-laki membandingkan reaksi terhadap pengalaman-pengalaman yang dimilikinya untuk 
memecahkan masalah pecahan. Tahap ini, subjek laki-laki menggunakan pengalamannya dengan membandingkannya, sehingga dapat memecahkan masalah pecahan, sebagaimana dikemukakan oleh Rodgers (2002). Sejalan dengan pendapat Rudd (Choy \& Oo, 2012) bahwa, peran penting dari berpikir reflektif adalah bertindak sebagai sarana untuk mendorong pemikiran selama situasi pemecahan masalah, karena memberikan kesempatan untuk menggunakan pengetahuan dan pengalaman yang berkaitan dengan masalah yang dihadapi dan memikirkan strategi terbaik untuk mencapai tujuan.

Selanjutnya, profil berpikir reflektif subjek laki-laki pada komponen contemplating dalam pemecahan masalah pecahan, dapat dilihat pada diagram berikut.

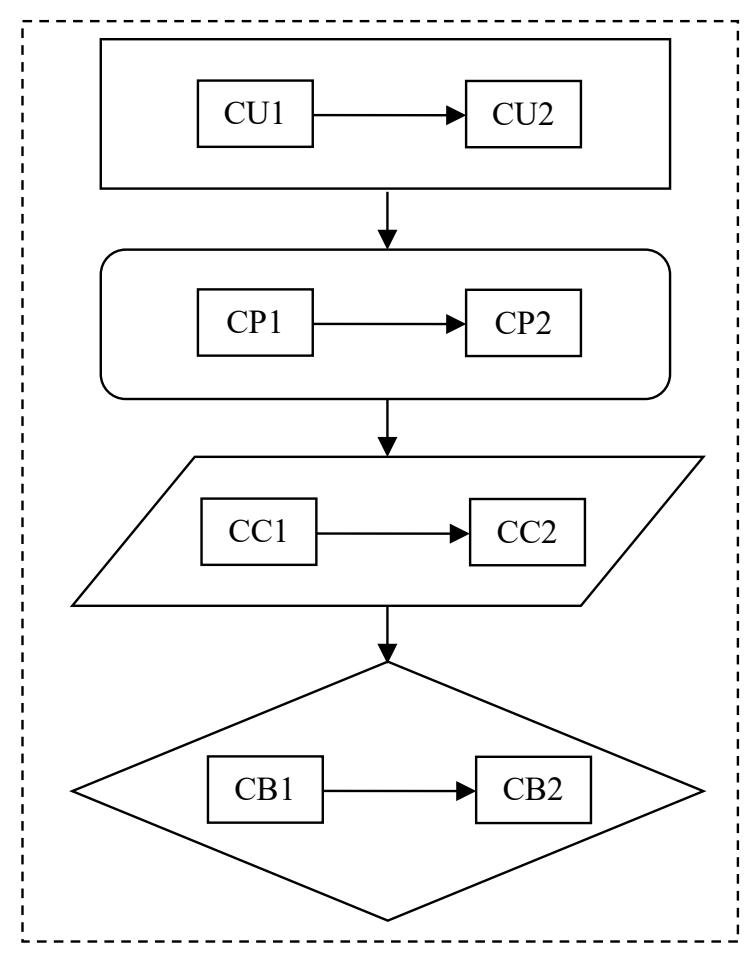

Gambar 3 Berpikir Reflektif Subjek Laki-laki pada Komponen Contemplating dalam Pemecahan Masalah Pecahan

Keterangan:

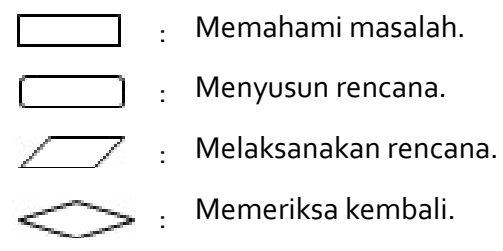

\begin{tabular}{|c|c|c|}
\hline $\mathrm{CU}_{1}$ & . & $\begin{array}{l}\text { Mempertimbangkan dan meyakini } \\
\text { bahwa informasi yang diberikan sudah } \\
\text { cukup untuk memecahkan masalah } \\
\text { pecahan. }\end{array}$ \\
\hline $\mathrm{CU}_{2}$ & : & $\begin{array}{l}\text { Mengungkapkan bahwa informasi- } \\
\text { informasi pada masalah yang diberikan } \\
\text { penting dan diperlukan semua untuk } \\
\text { memecahkan masalah tersebut. }\end{array}$ \\
\hline $\mathrm{CP}_{1}$ & & $\begin{array}{l}\text { Meyakini setiap tahapan dari strategi/ } \\
\text { metode/langkah-langkah yang diren- } \\
\text { canakan untuk memecahkan masalah } \\
\text { pecahan dan sudah benar berdasarkan } \\
\text { konsep matematika. }\end{array}$ \\
\hline $\mathrm{CP}_{2}$ & : & $\begin{array}{l}\text { Mempertimbangkan bahwa strategi/ } \\
\text { metode/langkah-langkah yang diren- } \\
\text { canakan sudah benar berdasarkan } \\
\text { pengalamannya. }\end{array}$ \\
\hline $\mathrm{CC}_{1}$ & . & $\begin{array}{l}\text { Meyakini strategi/metode/langkah- } \\
\text { langkah yang telah dilakukan sudah } \\
\text { benar. }\end{array}$ \\
\hline $\mathrm{CC}_{2}$ & . & $\begin{array}{l}\text { Mengevaluasi kesalahan dan segera } \\
\text { memperbaikinya. }\end{array}$ \\
\hline $\mathrm{CB}_{1}$ & & $\begin{array}{l}\text { Menyebutkan kesimpulan yang diper- } \\
\text { oleh setelah memecahkan masalah } \\
\text { yang diberikan. }\end{array}$ \\
\hline $\mathrm{CB}_{2}$ & & $\begin{array}{l}\text { Meyakini jawaban yang diperoleh } \\
\text { merupakan solusi dari masalah yang } \\
\text { diberikan setelah mempertimbangkan } \\
\text { berdasarkan pengalamannya. }\end{array}$ \\
\hline
\end{tabular}

Pada komponen contemplating, subjek laki-laki telah mempertimbangkan dan meyakini apa yang dilakukan untuk memecahkan masalah pecahan serta mengevaluasi kesalahan dengan segera memperbaikinya. Hal ini sesuai dengan yang dikemukakan oleh Taggart \& Wilson (2005) bahwa, berpikir reflektif berarti seseorang secara logis dalam memutuskan sesuatu dan menilai konsekuensi dari keputusan yang telah dibuat. Selain itu, sesuai dengan hasil temuan Gurol (2011) yang menyatakan bahwa berpikir reflektif sebagai proses kegiatan terarah dan tepat di mana individu menganalisis, mengevaluasi, memotivasi, mendapatkan makna yang mendalam dan menggunakan strategi yang tepat.

\section{Profil Berpikir Reflektif Subjek Perem- puan dalam Pemecahan Masalah Pecahan}

Berdasarkan hasil penelitian, subjek perempuan melakukan semua komponen berpi- 
kir reflektif melalui tahapan-tahapan pemecahan masalah. Profil berpikir reflektif subjek perempuan pada komponen reacting dalam pemecahan masalah pecahan, dapat dilihat pada diagram berikut.

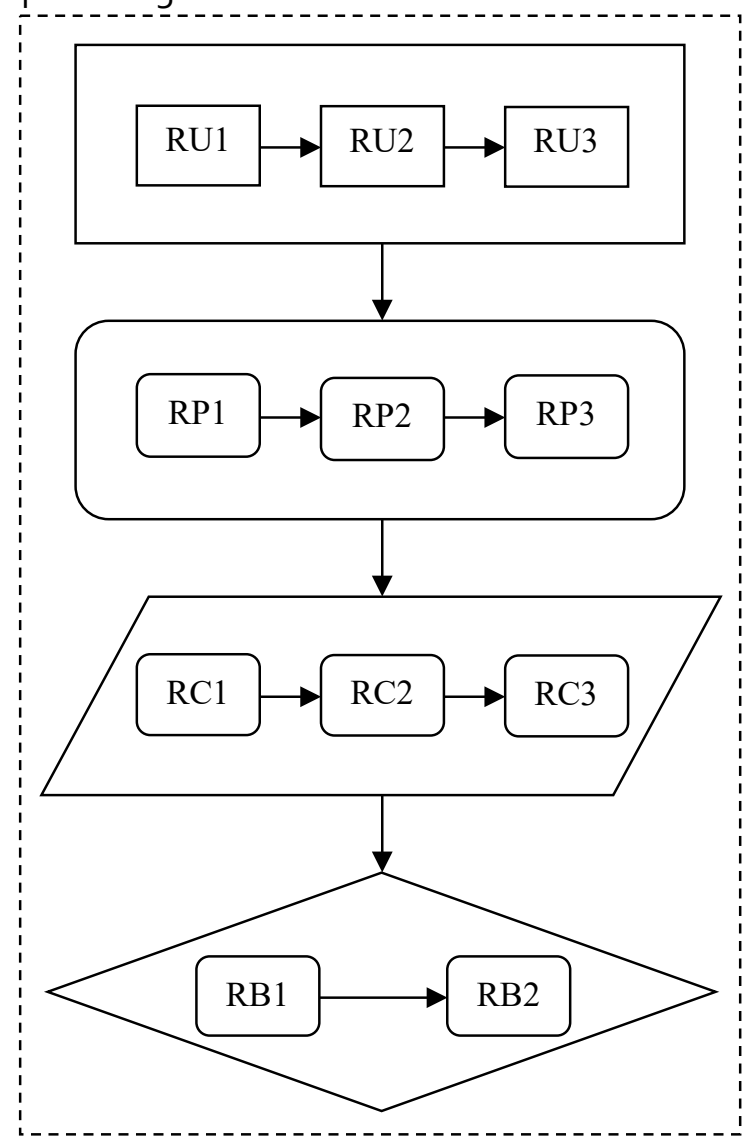

Gambar 4 Berpikir ReflektifSubjek Perempuan pada Komponen Reacting dalam Pemecahan Masalah

Pecahan

Keterangan:

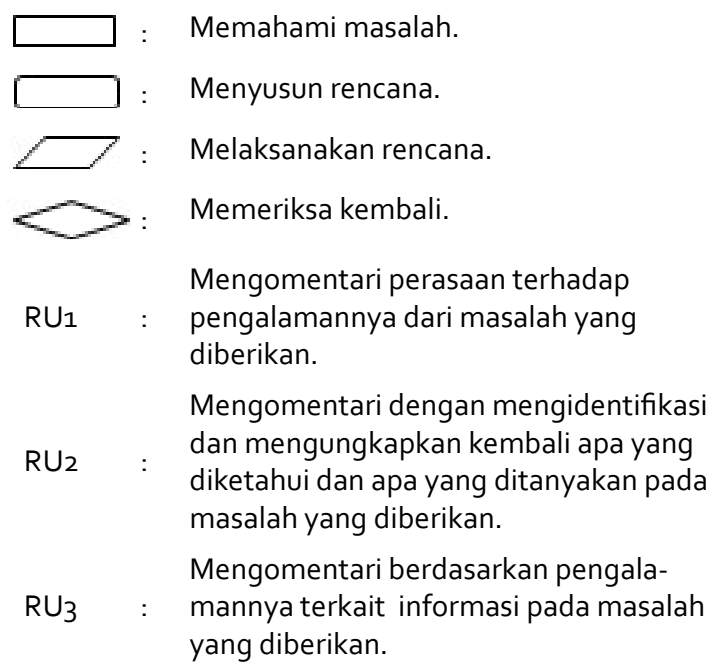

Mengomentari perasaan terhadap pen$\mathrm{RP}_{1}$ : galamannya dalam menyusun rencana pada masalah yang diberikan.

Mengomentari terhadap pengalaman$\mathrm{RP}_{2}$ : nya dengan menyebutkan rencana yang akan dilakukan untuk memecahkan masalah yang diberikan. $\mathrm{RP}_{3}:$ : strategi/ metode/langkah-langkah tersebut.

Mengomentari perasaan mengenai $\mathrm{RC}_{1}$ : langkah-langkah/perhitungan yang telah dilakukan dalam memecahkan masalah yang diberikan.

Mengomentari terhadap pengalamannya terkait strategi/metode/langkahlangkah untuk memecahkan masalah yang diberikan.

Mengomentari langkah yang telah di$\mathrm{RC}_{3}$ : lakukan dan kesesuaian rencana dengan langkah yang telah dilakukan untuk memecahkan masalah yang diberikan.

Mengomentari perasaan mengenai RB1 : langkah-langkah yang telah dilakukan memperoleh solusi dari masalah yang diberikan.

Mengomentari terhadap pengalaman$\mathrm{RB}_{2}$ : nya terkait mengenai perlunya memeriksa kembali pekerjaannya dan melihat kembali hasil akhir yang diperoleh.

Alur berpikir reflektif.

Pada komponen reacting, subjek perempuan mengomentari perasaannya terhadap pengalaman-pengalaman yang dimiliki terkait masalah pecahan yang diberikan, sehingga dia mengidentifikasi dan mengungkapkan kembali informasi-informasi dari masalah pecahan berdasarkan pengalamannya, menyusun rencana berdasarkan pengalamannya, melaksanakan rencana berdasarkan pengalamannya melakukan dan memeriksa kembali. Hal ini sesuai dengan yang dikemukakan Sezer (Choy \& Oo, 2012) bahwa, siswa yang berpikir reflektif menjadi sadar tentang apa yang mereka ketahui dan apa yang mereka butuhkan. Selanjutnya, subjek selalu menggunakan pengalaman-pengalaman yang dimilikinya dalam memecahkan masalah pecahan. Sebagaimana yang dikemukakan Rodgers (2002) bahwa, berpikir reflektif adalah proses bermakna yang memindahkan siswa dari suatu pengalaman ke pengalaman selanjutnya dengan pemahaman yang lebih 
mendalam tentang hubungannya dengan pengalaman dan ide yang lain.

Profil berpikir reflektif subjek perempuan pada komponen elaborating dalam pemecahan masalah pecahan, dapat dilihat pada diagram berikut.

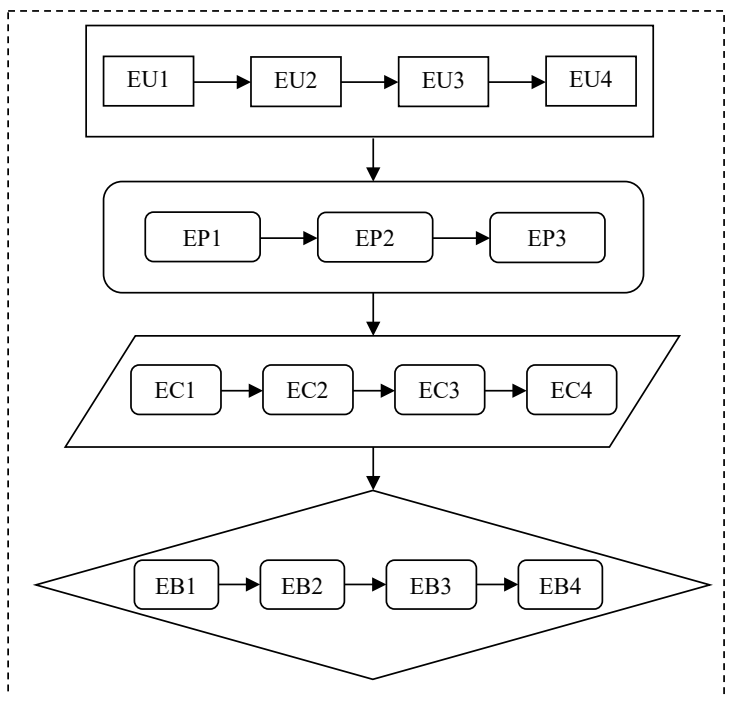

Gambar 5 Berpikir Reflektif Subjek Perempuan pada Komponen Elaborating dalam Pemecahan Masalah Pecahan

Keterangan:

\begin{tabular}{|c|c|c|}
\hline & : & Memahami masalah. \\
\hline & : & Menyusun rencana. \\
\hline & : & Melaksanakan rencana. \\
\hline & & Memeriksa kembali. \\
\hline $\mathrm{EU}_{1}$ & : & $\begin{array}{l}\text { Menyebutkan pengalamannya yang } \\
\text { berhubungan dengan masalah yang } \\
\text { diberikan. }\end{array}$ \\
\hline $\mathrm{EU}_{2}$ & : & $\begin{array}{l}\text { Menyebutkan persamaan dan } \\
\text { perbedaan dengan pengalamannya } \\
\text { berkaitan informasi yang diberikan } \\
\text { pada masalah. }\end{array}$ \\
\hline $\mathrm{EU}_{3}$ & : & Menyebutkan sebuah konsep/definisi. \\
\hline $\mathrm{EU}_{4}$ & : & $\begin{array}{l}\text { Menjelaskan kaitan antara informasi } \\
\text { yang diperoleh. }\end{array}$ \\
\hline$E P_{1}$ & : & $\begin{array}{l}\text { Menyebutkan dan menjelaskan } \\
\text { pengalamannya dalam menyusun } \\
\text { rencana. }\end{array}$ \\
\hline $\mathrm{EP} 2$ & : & $\begin{array}{l}\text { Menyebutkan persamaan dan perbe- } \\
\text { daan dengan pengalamannya terkait } \\
\text { strategi/metode/langkah-langkah } \\
\text { yang direncanakan. }\end{array}$ \\
\hline $\mathrm{EP}_{3}$ & & $\begin{array}{l}\text { Menyebutkan rencana lain atau cara } \\
\text { lain untuk memecahkan masalah yang } \\
\text { diberikan. }\end{array}$ \\
\hline
\end{tabular}

EC1 : Menyebutkan dan menjelaskan pengalamannya melakukan dalam melaksanakan rencana.

EC2 : Menyebutkan persamaan dan perbedaan dengan pengalamannya terkait strategi/metode/langkah-langkah yang telah dilakukan.

EC3 : Menjelaskan hubungan setiap langkah yang telah dilakukan dalam memecahkan masalah yang diberikan.

$\mathrm{EC}_{4}$ : Menyebutkan dan menjelaskan cara atau langkah lain untuk memecahkan masalah yang diberikan.

EB1 : Menyatakan terhadap pengalamannya bahwa pernah memeriksa kembali jawabannya.

EB2 : Menyebutkan persamaan dan perbedaan dengan pengalamannya terkait memeriksa kembali solusi yang diperoleh.

EB3 : Mengungkapkan kesesuaian yang diperoleh dengan strategi/metode/langkah-langkah yang telah direncanakan dan atau yang telah dilakukan.

EB4 : Menuliskan alternatif penyelesaian yang lain dan alternatif pemecahan yang terbaik.

Alur berpikir reflektif.

Pada komponen elaborating, subjek perempuan membandingkan reaksi terhadap pengalaman-pengalaman yang dimilikinya untuk memecahkan masalah pecahan. Tahap ini, subjek menggunakan pengalamannya dengan membandingkannya, sehingga dapat memecahkan masalah pecahan, sebagaimana dikemukakan oleh Rodgers (2002). Sejalan dengan pendapat Rudd (Choy \& Oo, 2012) bahwa, peran penting dari berpikir reflektif adalah bertindak sebagai sarana untuk mendorong pemikiran selama situasi pemecahan masalah, karena memberikan kesempatan untuk menggunakan pengetahuan dan pengalaman yang berkaitan dengan masalah yang dihadapi dan memikirkan strategi terbaik untuk mencapai tujuan.

Setelah itu, profil berpikir reflektif subjek perempuan pada komponen contemplating dalam pemecahan masalah pecahan, dapat dilihat pada diagram berikut. 


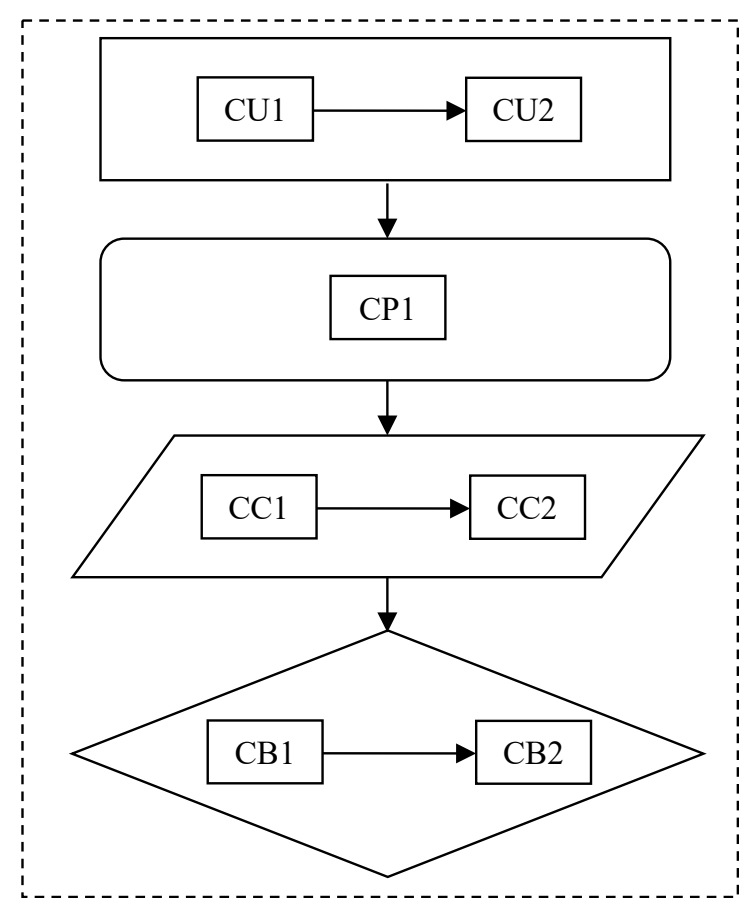

Gambar 6 Berpikir Reflektif Subjek Perempuan pada Komponen Contemplating dalam Pemecahan Masalah Pecahan

Keterangan:

\begin{tabular}{|c|c|c|}
\hline & & Memahami masalah. \\
\hline & : & Menyusun rencana. \\
\hline & : & Melaksanakan rencana. \\
\hline & & Memeriksa kembali. \\
\hline CU1 & : & $\begin{array}{l}\text { Mempertimbangkan dan meyakini bahwa } \\
\text { informasi yang diberikan sudah cukup un- } \\
\text { tuk memecahkan masalah pecahan. }\end{array}$ \\
\hline CU2 & : & $\begin{array}{l}\text { Mengungkapkan bahwa informasi-infor- } \\
\text { masi pada masalah yang diberikan penting } \\
\text { dan diperlukan semua untuk memecahkan } \\
\text { masalah tersebut. }\end{array}$ \\
\hline $\mathrm{CP} 1$ & : & $\begin{array}{l}\text { Meyakini setiap tahapan dari strategi/ me- } \\
\text { tode/langkah-langkah yang direncanakan } \\
\text { untuk memecahkan masalah pecahan dan } \\
\text { sudah benar berdasarkan konsep matema- } \\
\text { tika. }\end{array}$ \\
\hline $\mathrm{CC} 1$ & : & $\begin{array}{l}\text { Meyakini strategi/metode/langkah-langkah } \\
\text { yang telah dilakukan sudah benar. }\end{array}$ \\
\hline $\mathrm{CC} 2$ & : & $\begin{array}{l}\text { Mengevaluasi kesalahan dan segera mem- } \\
\text { perbaikinya. }\end{array}$ \\
\hline CB1 & : & $\begin{array}{l}\text { Menyebutkan kesimpulan yang diperoleh } \\
\text { setelah memecahkan masalah yang diberi- } \\
\text { kan. }\end{array}$ \\
\hline $\mathrm{CB} 2$ & : & $\begin{array}{l}\text { Meyakini jawaban yang diperoleh meru- } \\
\text { pakan solusi dari masalah yang diberikan } \\
\text { setelah mempertimbangkan berdasarkan } \\
\text { pengalamannya. }\end{array}$ \\
\hline & & Alur berpikir reflektif. \\
\hline
\end{tabular}

Pada komponen contemplating, subjek perempuan meyakini apa yang dilakukan untuk memecahkan masalah pecahan serta mengevaluasi kesalahan dengan segera memperbaikinya. Hal ini sesuai dengan yang dikemukakan oleh Taggart \& Wilson (2005) bahwa, berpikir reflektif berarti seseorang secara logis dalam memutuskan sesuatu dan menilai konsekuensi dari keputusan yang telah dibuat.

\section{SIMPULAN}

\section{Profil Berpikir Reflektif Siswa Laki-laki dalam Pemecahan Masalah Pecahan}

Siswa laki-laki melakukan reacting pada setiap tahapan pemecahan masalah. Pada tahap memahami masalah, dia mengomentari perasaannya terhadap pengalaman yang dimiliki yang terkait informasi-informasi pada masalah pecahan. Pada tahap menyusun rencana, siswa ini mengomentari perasaannya terhadap pengalaman yang dimiliki terkait strategi/ metode/langkah-langkah yang direncanakan untuk memecahkan masalah pecahan. Pada tahap melaksanakan rencana, dia mengomentari perasaannya terhadap pengalaman yang dimiliki terkait strategi/metode/ langkah-langkah yang telah dilakukan dengan yang telah disusun dalam memecahkan masalah pecahan. Selanjutnya, pada tahap memeriksa kembali, siswa ini mengomentari perasaannya terhadap pengalaman yang dimiliki tentang memeriksa solusi yang diperoleh dari jawaban akhir dari masalah pecahan.

Siswa laki-laki melakukan elaborating pada setiap tahapan pemecahan masalah. Pada tahap memahami masalah, siswa ini membandingkan reaksi terhadap pengalaman-pengalaman yang dimiliki terhadap informasi-informasi pada masalah pecahan terkait penggunaan konsep dan hubungan antara informasi yang diperoleh. Pada tahap menyusun rencana, dia membandingkan reaksi terhadap pengalaman-pengalaman melakukan terkait strategi/metode/ langkahlangkah yang direncanakan untuk memecahkan masalah pecahan. Pada tahap melaksanakan rencana, siswa ini membandingkan reaksi terhadap pengalaman-pengalaman melakukan terkait strategi/metode/langkah-langkah 
yang telah dilakukan dalam memecahkan masalah pecahan. Kemudian pada tahap memeriksa kembali, dia membandingkan reaksi terhadap pengalaman-pengalaman melakukan mengenai memeriksa kembali dan kesesuaian antara hasil pemecahan masalah pecahan dengan masalah pecahan yang diberikan serta menemukan solusi pemecahan masalah terbaik.

Siswa laki-laki melakukan contemplating pada setiap tahapan pemecahan masalah. Pada tahap memahami masalah, dia mempertimbangkan dan meyakini bahwa informasi yang diberikan sudah cukup untuk memecahkan masalah pecahan. Pada tahap menyusun rencana, siswa ini mempertimbangkan dan meyakini bahwa strategi/ metode/langkah-langkah yang direncanakan dapat memecahkan masalah pecahan dan sudah benar berdasarkan konsep matematika. Pada tahap melaksanakan rencana, dia mempertimbangkan dan meyakini bahwa strategi/ metode/langkah-langkah yang telah dilakukan sudah benar dalam memecahkan masalah pecahan serta mengevaluasi kesalahan dan segera memperbaikinya. Kemudian pada tahap memeriksa kembali, siswa ini dapat menentukan dan meyakini mengenai simpulan yang diperoleh setelah memecahkan masalah pecahan.

\section{Profil Berpikir Reflektif Siswa Perem- puan dalam Pemecahan Masalah Pecahan}

Siswa perempuan melakukan reacting pada setiap tahapan pemecahan masalah. Pada tahap memahami masalah, dia mengomentari perasaannya terhadap pengalaman yang dimiliki yang terkait informasi-informasi pada masalah pecahan. Pada tahap menyusun rencana, siswa ini mengomentari perasaannya terhadap pengalaman yang dimiliki terkait strategi/metode/langkah-langkah yang direncanakan untuk memecahkan masalah pecahan. Pada tahap melaksanakan rencana, siswa ini mengomentari perasaannya terhadap pengalaman yang dimiliki terkait strategi/ metode/langkah-langkah yang telah dilakukan dengan yang telah disusun dalam meme- cahkan masalah pecahan. Selanjutnya pada tahap memeriksa kembali, dia mengomentari perasaannya terhadap pengalaman yang dimiliki tentang memeriksa solusi yang diperoleh dari jawaban akhir dari masalah pecahan.

Siswa perempuan melakukan elaborating pada setiap tahapan pemecahan masalah. Pada tahap memahami masalah, dia membandingkan reaksi terhadap pengalaman-pengalaman yang dimiliki terhadap informasi-informasi pada masalah pecahan terkait penggunaan konsep dan hubungan antara informasi yang diperoleh. Pada tahap menyusun rencana, siswa ini membandingkan reaksi terhadap pengalaman-pengalaman melakukan terkait strategi/metode/ langkahlangkah yang direncanakan untuk memecahkan masalah pecahan. Pada tahap melaksanakan rencana, dia membandingkan reaksi terhadap pengalaman-pengalaman melakukan terkait strategi/metode/langkah-langkah yang telah dilakukan dalam memecahkan masalah pecahan. Kemudian pada tahap memeriksa kembali, siswa ini membandingkan reaksi terhadap pengalaman-pengalaman melakukan mengenai memeriksa kembali dan kesesuaian antara hasil pemecahan masalah pecahan dengan masalah pecahan yang diberikan serta menemukan solusi pemecahan masalah terbaik.

Siswa perempuan melakukan contemplating pada setiap tahapan pemecahan masalah. Pada tahap memahami masalah, dia mempertimbangkan dan meyakini bahwa informasi yang diberikan sudah cukup untuk memecahkan masalah pecahan. Pada tahap menyusun rencana, siswa ini meyakini bahwa strategi/metode/langkah-langkah yang direncanakan dapat memecahkan masalah pecahan dan sudah benar berdasarkan konsep matematika. Pada tahap melaksanakan rencana, siswa ini meyakini bahwa strategi/metode/ langkah-langkah yang telah dilakukan sudah benar dalam memecahkan masalah pecahan serta mengevaluasi kesalahan dan segera memperbaikinya. Kemudian pada tahap memeriksa kembali, dia dapat menentukan dan meyakini mengenai simpulan yang diperoleh setelah memecahkan masalah pecahan. 


\section{DAFTAR PUSTAKA}

Choy, S.C., \& Oo, P.S. (2012). Reflective thinking and teaching practices: A precursor for incorporating critical thinking into the classrom? International Journal of Instructuon, 5(1), 167-182. (e-ISSN: 1308-1470).

Clarke, D., Roche, A., \& Mitchell, A. (2008). Practical tips for making fractions come alive and make sense. Mathematics Teaching in The Middle School, 13(7), $372-380$.

Demirel, M., Derman, I., \& Karagedik, E. (2015). A study on the relationship between reflective thinking skills towards problem solving and attitudes towards mathematics. 7th World Conference on Educational Sciences, (WCES-2015), o5-07 February 2015, Novotel Athens Convention Center, Athens, Greece. Faculty of Education. Hacettepe University. Ankara, Turkey.

Depdiknas. (2006). Peraturan Menteri Pendidikan Nasional nomor 23 tahun 2006 tentang Standar Kompetensi Lulusan untuk Satuan Pendidikan Dasar dan Menengah. Jakarta.

Dewey, J. (1933). How we think: A restatement of the relation of reflective thinking to the educative process. Lexington, Massachusetts: D.C. Heath and Company.

Fisher, A. (2008). Critical thinking: An introduction. Jakarta: Erlangga.

Fisher, J. (2009). Fraction, partitioning and the partwhole concept. Teaching and Learning. Hal. 12 -19 .

Gurol. A. (2011). Determining the reflective thinking skills of pre-service teachers in learning and teaching process. Energy Education Science and Technology Part B: Social and Educational Studies 2011 Volume (issue) 3(3): 387-402.

Hudojo, H. (2003). Pengembangan kurikulum dan pembelajaran matematika. Malang: Universitas Negeri Malang.

Jacob, S. M., \& Sam, H. K. (2008). Measuring critical thinking in problem solving through online discussion forums in first year university mathematics. Proceedings of the International MultiConference of Engineers and Computer Scientists 2008 Vol I. IMECS 2008, 19-21 March, 2008, Hong Kong. ISBN: 978-988-98671-8-8.

King, F. J., Gudson, L., \& Rohani, F. (2013). Higher order thinking skills. Miami: Cala Press.

Lamon, S. J. (2012). Teaching fraction and rations for understanding: essential content knowledge and instructional strategies for teacher ( ${ }^{\text {rd }}$ Ed). USA: Taylor and Francis.

Meissner, H. (2006). Creativity and mathematics education. Elementary Education Online, 5(1), 65-72.

Miles, M. B., Huberman, A. M., \& Saldaña, J. (2014). Qualitative data analysis: A methods sourcebook.
Edition 3. Arizona State University: SAGE Publication. Inc.

Muin, A. (2011). The situations that can being reflective thinking process in mathematics learning. International Seminar and the Fourth National Conference on Mathematics Education 2011 Department of Mathematics Education. Yogyakarta State University 234 Yogyakarta.

NCTM. (2000). Principles and standards for school mathematics. Reston. VA: National Council of Teacher of Mathematics.

Ngang, T. K., Nair, S., \& Pracak, B. (2013). "Developing instruments to measure thinking skills and problem solving skills among malaysian primary school pupils". Social and Behavioral Sciences 116 (2014) 3760-3764.

Odafe, V. J. (2008). Teaching and learning mathematics: Student reflective adds a new dimension. Bowling Green State University, Huron. USA.

Pargulski, J. R., \& Reynolds, M. R. (2017). Sex differences in achievement: Distributions matters. Personality and Individual Differences 104 (2017) 272 - 278.

Polya, G. (1973). How to solve it. Princeton, NJ: Princeton University Press.

Rodgers, C. (2002). Defining reflection: Another look at John Dewey and reflective thinking. Teacher College Record, Volume 104, Number 4, pp. 842 866. Columbia University 0161-4681.

Sabandar, J. (2010). Berpikir reflektif dalam pembelajaran matematika. Tersedia pada http://file.upi.edu/ Direktori/FPMIPA/...MATEMATIKA/.../Berpikir_ Reflektif2.pdf. Diakses pada tanggal 29 Oktober 2016.

Santrock, J. W. (2011). Educational psychology $5^{\text {th }}$ edition. New York: Published by McGraw-Hill.

Suherman, E. (2001). Strategi pembelajaran matematika kontemporer. Bandung: JICA-UPI.

Surbeck, E., Han, E. P., \& Moyer, J. (1991). "Assessing reflective responses in journals". Educational Leadership 48, pp. 25-27. (EJ 422 850).

Taggart, G. L., \& Wilson, A. P. (2005). Promoting reflective thinking in teacher 50 action strategies. Thousand Oaks, California: Corwin Press.

Tomasello, M. (2014). A natural history of human thinking. New York: Harvard University Press.

Tuncer, M., \& Ozeren, E. (2013). "Prespective teachers' evalutions in terms of using reflective thinking skill to solve problems". Social and Behavioral Sciences 51 (2012) 666-671.

Van De Walle, J. A. (2008). Matematika sekolah dasar dan menengah. Edisi keenam. Jakarta: Erlangga.

Zhu, Z. (2007). Gender differences in mathematical problem solving patterns: A review of literature. International Education Journal. 2007, 8 (2) Shannon Research Press, 8 (2): 187-203. 